Н.С.Воронова, кандидат філософських наук, дочент ДДПУ

О.В.Прокопенко, кандидат філософських наук, дочент ДДПУ

\title{
ФІЛОСОФІЯ СИМФОНІЗМУ УКРАЇНСЬКОЇ МУЗИКИ
}

Для української музики характерні не тільки емоційність [1], не тільки пісенність [2], про що ми вже писали в інших статтях, а й симфонізм. Дослідження філософії симфонізму української музики зумовлюється насамперед тим, що симфонія у XX, на початку XXI століття лишаючись музичним жанром, набуває соціокультурного значення в контексті метажанру. Адже іiі засобами створюється особлива інтонаційна система мистецтва, в музичній формі якої постають одвічні питання сенсу життя, змісту історії.

Оркестрове звучання, як світова подія, свідками та учасниками якої $є$ і виконавці, і вся слухацька аудиторія, немовби наближує ці філософські питання до проблем людини в їі теперішньому існуванні, оскільки концептуалізація часу відбувається на «перехресті» просторово-часових вимірів історії. Людина поринає у звуки симфонії, в яких завдяки жанрово-стильовим засобам співіснують образи, які «цитують» різні культурні пласти. Оперування кодом інформаційної пам'яті жанру дає змогу висвітлити у симфонічному творі глибинний семантичний зріз, зокрема «у тих випадках, коли композитор апелює до жанрів, які мають особисту історію розквіту та занепаду, котрі «законсервовані» у рамках певної епохи і тим самим відсилають слухача до конкретного, визначеного часового ареалу $[3,200] »$. Отже, симфонія концентрує ментальні виміри культури: світогляд язичницький, християнський, позбавляючись від меж глибинної пам'яті надає людині можливість ідентифікувати себе не лише тільки в буденному варіанті, а й у контексті історичного часу та соціального простору.

Щодо місця та ролі української музики в загальноєвропейському контексті слід зазначити, що саме в цьому жанрі твори сучасних українських композиторів сягнули таких творчих висот, які 
зумовили ставлення до українського симфонізму як до одного 3 найкращих у сучасному європейському мистецтві.

Названі процеси безпосередньо пов'язані з оновленням драматургії симфонії. У межах одного твору традиційна фабульна драматургія стикається з іншими типами драматургії - монтажним, ігровим, медитативним. Цим пояснюється великий діапазон та нефіксованість жанру в творчості навіть одного композитора. Стабільність лишається на рівні сутності симфонії, тобто філософського узагальнення та концептуальності художнього мислення.

Осмислити філософію симфонізму української музики стає можливим за відповідного підходу до цієї проблеми. В сучасному музикознавстві наукову методику системного визначення принципів розвитку українського симфонізму викладено грунтовній монографії О.Зінькевич «Динамика обновления» [4]. Слід також зауважити, що попри ті обставини, коли різні аспекти української музики стають предметом наукового аналізу багатьох вчених (В. Іванченко [5], І.Коханик [6], М.Ржевська [7; 8], І. Тукова [9], Ю. Чекан [10] та ін.), дослідження О.Зінькевич донині лишаються єдиним, в якому здійснено цілісний аналіз зростаючої ролі українського симфонізму в загальноєвропейській музичній культурі.

Метою нашої розвідки є дослідити магістральні вектори розвитку філософії симфонізму української музики. Задля поставленої мети слід: визначити концептуальні виміри, що визначають специфіку українського симфонізму; висвітлити філософію авторського новаторства української симфонії; схарактеризувати процеси взаємодії симфонічних жанрів із різними видами мистецтва. Базовим для вирішення поставлених завдань $\epsilon$ генетико-типологічний метод аналізу.

Жанровий напрям драматичної симфонії в українській музиці визначено в творчості Б.Лятошинського та А.Штогаренка в площині «виділення епічної драми (Третя симфонія Б.Лятошинського), лірикодраматичної симфонії (Друга - А. Штогаренка) та монологічної драми (Четверта - Б. Лятошинського)» [4, 40]. Симфонічна драма і надалі зберігає концептуальну цілісність та стабільність, проте розширюється діапазон драматургічних рішень.

Однією $з$ характеристик наступного періоду цього напряму стає опора на симфонічний досвід як української, так і російської школи, зокрема на творчість Б. Лятошинського, С. Прокоф'єва, Д. Шостаковича. Насамперед цей вимір розвитку симфонічної драми вирізняє композиторську діяльність Ю.Іщенка. Подальший етап цього жанру, 
уособлений такими творами, як Перша симфонія Є.Станковича, Четверта симфонія В.Сільвестрова, демонструє високий рівень узагальнення як європейського, так і національного досвіду, що спричинює особливу помітну визначеність авторських рис у жанрі симфонічної драми.

У творчу полеміку засобами симфонічної драми вступає В.Сильвестров в Четвертій симфонії. Це - «трагічно змальована симфоніясповідь, симфонія-роздуми. В ній є й ракурс споглядання, і збуджене биття думки, що живе надією на перемогу духовності в людині» $[4,75]$. Своєрідне рішення форми привертає увагу як музичного критика, так і реципієнта та дивує власною некерованістю супротив законів жанру. Проте аналіз знаходить в атиповій формі обмірковану конструкцію, сувору логіку драматичного розгортання. Динамічність розвитку симфонічної драми, неперервний зв'язок із попередниками в музичній тканині позначений жанровими орієнтирами: ритм сарабанди, пассакалія, що поступово виростає з надр симфонії. Через ці жанри відбуваються завоювання просторовості в музиці та змінювання в сприйнятті часу, пов'язані із свідомим застосуванням динамічних, темпових контрастів, стилістичних антитез. Своєрідну лінію музичної пам'яті створюють темброві характеристики інструментів, оскільки вони сприяють тому, що реципієнт згадує симфонії Г. Малера, П. Чайковського. На нашу думку, назване становить особливий сенс філософії симфонізму, згідно з якою композитор інтонаційними засобами створює емоційну атмосферу, що надихає слухача звернутися в музичній пам'яті до попереднього симфонічного досвіду, обміркувати його значення в сучасному житті.

Типові риси симфонії-драми наявні в творчості В.Сильвестрова: тугий вузол конфлікту з хвильовою розробкою та інтонаційним інтегруванням. Проте зусилля змінити драматургічні рівні симфонії спричинюють креативне переосмислення суворих меж форми. Структурно-композиційний обсяг симфонії позначений накладанням однієї музичної сфери на іншу, нібито кожна структура міститься в попередній, що зумовлено жанровою цілісністю «симфоніїроздуму». Назване, як вважає О. Зінькевич, становить також специфіку «відсутності самої події», оскільки концептуальне вирішення твору це роздуми Людини про зміст життя, про сенс існування.

На нашу думку, драматургічні, структурно-композиційні рівні змін симфонічного жанру в творчості В.Сильвестрова визначає особлива авторська позиція. Певною мірою можна стверджувати, 
що саме філософія симфонізму стає інструментом, засобом і водночас символом, який не визначає форму твору,а опосередковує власне композиторське кредо митця.

Риси оновлення симфонічної драми в творах Ю. Іщенка (Третя симфонія) наявні насамперед у сфері драматургії. Водночас у симфонії відсутні концептуальні відкриття, радикальні новації в сфері музичної мови, композиторської техніки. Автор не змінює типологію жанру, але суттєво перетворює іiі. Такий еволюційний тип новації дослідники визначають оригінальністю та спадкоємністю на одному рівні. Цей новаційний тип також сприяє значним художнім досягненням, одним із яких іє Третя симфонія Ю. Іщенка.

Отже, філософія симфонізму - драматична; будучи подією загальноєвропейського рівня, вона динамічно розвивається в українській музиці. Мистецьким успіхом є узагальнення досвіду попередніх надбань європейської, української, російської симфонії, творчий підхід до всього матеріалу та вихід на рівень полілогу художниківособистостей. Музичне слово митця в драматичній симфонії немовби концентрує конфлікт своєї епохи та повідомляє про нього сучасникам. Проте це не відчай самотньої людини, стиснутої пресом соціальних подій, а висловлення митця, яким він бере участь у всій метажанровій структурі сучасного мистецтва. Відтак він продовжує попередників, звертаючись до нащадків.

У філософії епічної симфонії можна вирізнити дві головні тенденції: пошук нових драматургічних рішень в умовах жанрової стабільності та активну типологічну взаємодію, яка виходить на рівень інтегрування та викликає появу нових жанрових структур. Перша тенденція орієнтована на змістову традицію вітчизняного симфонічного епосу, зокрема на творчість Б. Лятошинського, продовжуючи розвиток жанру епічної симфонії в цьому напрямі. Її представниками $€$ Ю. Іщенко (Четверта та П’ята симфонії), Г. Ляшенко (Третя симфонія) А. Штогаренко. Друга, інноваційна, тенденція дістала вираження у творчості І.Карабиця та Є. Станковича. 3 іменами цих композиторів пов'язані значні типологічні перетворення, які сприяють оновленню філософії симфонічного епосу.

Креативні зміни філософії епічної симфонії зумовлені особливим розуміння епічного в композиторській діяльності І.Карабиця та Є.Станковича, яке базується на часових вимірах історії. О.Зинькевич зазначає, що епічним часом можуть стати «цілісно-історична пам'ять народу» (згадаймо твір І.Карабіца «П'ять пісень про Україну») та 
певна історична подія (Третя симфонія) Є.Станковича «Я стверджуюсь». «Замість абсолютного епічного минулого» - конкретна історична епоха» $[4,108]$.

На нашу думку, філософський зміст епічної симфонії постає через дві різні ідеї. Перша ідея - образ-символ епічного, друга - епічна образність конкретної історичної події. Саме подвійна образність епічної симфонії визначає тематичний матеріал симфонізму, що зумовлює дві форми - взаємодії та синтезу з іншими видами мистецтва. Програмна заданість і пряме звернення до літературних творів форма синтезу. Щодо опосередкованої взаємодії, то в цій формі асоціативні плани засвідчують фольклорні жанри епічного змісту, насамперед думи, і визначають порівняльні характеристики з ментальноспорідненими літературними творами О.Гончара, М. Стельмаха.

У філософії симфонізму української музики, в якій генеруючою природою була пісня, відбулось збагачення змісту та художніх форм жанрів вокальної природи. Українська ментальність органічно пов'язана 3 кантовою творчістю, що має широкий вияв у тематизмі й образній сфері не тільки вокальних, а й інструментальних жанрів. Співіснування в національній традиції лінійного та поліфонічного мислення мало помітне значення в процесі асиміляції з жанрами західноєвропейської музики. Зокрема, це дало змогу авторам партесних концертів сприйняти такий тип викладу, який мав в своїй основі вертикальні конструкції та водночас мусив підтримувати мелодійний рух багатоголосся (традиційний в українській пісенній культурі) 3 досить складними поліфонічними прийомами. Як прояв національної інтенції, подвійний тип мислення вплинув також на рівнозначні в соціокультурному аспекті, але відмінні в жанровій формі і типах музичного мислення духовний та партесний концерти. Поряд з гармонічною фактурою в духовних концертах наявна і поліфонічна, яка має якісно нову рису - поєднання західноєвропейської жанровості та українського тематизму. У творчості М.Березовського і Д.Бортнянського відбувається синтез поліфонічної техніки фуги з українською народнопісенною основою.

Отже, однією $з$ концептуальних вимірів, що визначають специфіку філософії симфонізму української музики, є особлива відкритість, яка зумовлює синтез з родовою (епічна, лірична, драматична симфоніі) формою мистецтва. Виникають нові жанрові типи, кожен iз яких у творчості українських композиторів набуває концептуально авторського рішення. Процеси взаємодії симфонічних жанрів 
iз різними видами мистецтва обумовлюють два принципи синтезу прямий (програмність) та асоціативний (образність).

\section{ЛIТЕРАТУРА}

1. Воронова Н.С. Емоційна складова природи музичного мистецтва // Пошуки і знахідки. Матеріали наукової конференції СДПУ / Укладач В.К.Сарієнко. - Слов'янськ, 2011. - С.35-38.

2. Воронова Н.С. Універсальна складова естетичного виміру національної музики // Мультиверсум. Філософський альманах. - Вип. 2 (90). K., 2010. - C. 182-192.

3. Тукова I. Про функціонування інструментальних жанрів західноєвропейського бароко в українській музиці другої половини XX століття // Київське музикознавство. Зб. статей. - К., 2000 - Вип. 5. - С. 198-206.

4. Зинкевич E.C. Динамика обновления // Музычна Укр. - К., 1986. - 184 с.

5. Іванченко $B$. Програмність як творчий музичний процес в українській симфонії (досвід анлізу) // Музичний твір: проблема розуміння. Науковий вісник НМАУ ім. П.І.Чайковського. - К., 2002. - Вип. 20. - С.85-94.

6. Коханик I. Музичний твір: взаємодія стабільного і мобільного в аспекті стилю // Музичний твір: проблема розуміння / Науковий вісник НМАУ ім. П.І. Чайковського. - К., 2002. - Вип. 20. - С.44-51.

7. Ржевська $M$. Категорія національного та процеси самоутвердження i самопізнання української музичної культури (перша третина XX століття) // Музична україністика в контексті світової культури (науковометодичний збірник). Українське музикознавство. - К., 1998. - Вип. 28 C. 80-91.

8. Ржевська М. Періодизація українського музично-культурного процесу XX століття як проблема динаміки культури // Українське музикознавство. - К., 2000. - Вип. 29. - С.94-103.

9. Тукова И. «Жанротворчество» и творчество «в жанре» // Музичний твір як творчий процес. - К., 2002. - Вип. 21. - С.31-38.

10.Чекан Ю. «Оперний слід» в прозі Ю.Андуховича // Науковий вісник НМАУ ім. П.І.Чайковського. Чотири століття опери. Оперні школи XIX-XX ст. - К., 2000. - С. 125-131.

Воронова Н.С., Прокопенко О.В. Філософія симфонізму української музики.

Стаття присвячена з'ясуванню специфіки філософії симфонізму української музики. На прикладі творчих доробок вітчизняних композиторів показано, що концептуальним виміром $\epsilon$ особлива відкритість, яка 
зумовлює синтез із родовими формами мистецтва та виникнення нових жанрових типів, кожен із яких набуває авторського рішення. Окреслено програмний та образний принципи синтезу в процесі взаємодії симфонічних жанрів з різними видами мистецтва.

Ключові слова: філософія симфонізму, українська музика, форми мистецтва, жанр, симфонія.

Воронова Н.С., Прокопенко А.В. Философия симфонизма украинской музыки.

Статья посвящена выяснению специфики философии симфонизма украинской музыки. На примере произведений отечественных композиторов показано, что концептуальным измерением является особая открытость, которая обуславливает синтез с родовыми формами искусства и возникновение новых жанровых типов, каждый из которых приобретает авторское решение. Очерчены программный и образный принципы синтеза в процессе взаимодействия симфонических жанров с различными видами искусства.

Ключевые слова: философия симфонизма, украинская музыка, формы искусства, жанр, симфония.

Voronova N., Prokopenko A. Philosophy of Symphony in Ukrainian music.

The article is devoted to the elucidation of the specificity of philosophy of the Ukrainian Symphony music. On the example of works by Ukrainian composers revealed that the conceptual dimension is a special openness, which leads to the synthesis with generic forms of art and the emergence of new genre types, each of which acquires the author's solution. Outlined program and shaped the principles of synthesis in the process of interaction symphonic genres with different kinds of art.

Key words: philosophy of symphony, ukrainian music, art form, the genre, the symphony. 